\title{
THE RELATIONSHIP BETWEEN MATERNAL AND CHILD HEALTH SERVICES WITH THE PREVALENCE OF STUNTING BASED ON THE BASIC HEALTH RESEARCH IN INDONESIA
}

\author{
Demsa Simbolon, ${ }^{1}$ Dhea Adevianti ${ }^{1}$, Luluk Setianingsih ${ }^{1}$, Lisma Ningsih2, Lusi Andriani ${ }^{3}$ \\ ${ }^{1}$ Department of Nutrition Health Polytechnic Ministry of Health Bengkulu, Indonesia \\ ${ }^{2}$ Department of Health Promotion Ministry of Health polytechnic Bengkulu, Indonesia \\ ${ }^{3}$ PolytechnicDepartment of Obstetrics MoH Bengkulu, Indonesia \\ Correspondence address: Demsa Simbolon \\ Email: demsa_ui03@yahoo.com
}

\begin{abstract}
Stunting is a linear growth disorder considered as a serious health problem in Indonesia, where its prevalence is related to maternal and child health $(\mathrm{MCH})$ services. This study aimed to compare the coverage of maternal and child health services between two surveys and analyze how they relate to the prevalence of stunting. The study used aggregate data from the 2013 and 2018 Basic Health Research Reports using a cross-sectional approach. The research sample spanned to 34 provinces in Indonesia. Stunting prevalence was taken as aggregate data from individuals based on height-for-age z-scores (HAZ). The independent variable was the achievement of MCH service indicators. Data analysis used variance measures, correlations, simple linear regression, and paired T-tests. The results found variations in the prevalence of stunting, with $25.4 \%$ in 2013 and $25.1 \%$ in 2018 . There was a 7.4\% decrease in severe stunting prevalence between 2013 and 2018, but the decrease was not significant $(\mathrm{p}=$ 0.506). The analysis results of the 2013 Basic Health Research showed that MCH service indicators related to stunting prevalence were coverage of antenatal care, iron consumption, delivery by health personnel, delivery in health facilities, postpartum maternal health services, low birth weight (LBW) prevalence, neonatal examination, complete immunization, health card ownership, and growth monitoring. The analysis results of the 2018 Basic Health Research showed that $\mathrm{MCH}$ indicators were related to the prevalence of antenatal care coverage, delivery by health personnel, and delivery in health facilities, postpartum maternal health services, LBW prevalence, neonatal examination, and complete immunization. There was a significant increase in the coverage of $\mathrm{MCH}$ services from 2013 and 2018 ( $\mathrm{p}<0.0001$ ), except for the coverage of Fe tablet consumption, the prevalence of stunted birth babies, ownership of health cards, provision of vitamin A, and provision of colostrum. The better the coverage of $\mathrm{MCH}$ services, the lower the stunting prevalence. Efforts to improve the $\mathrm{MCH}$ service programs are required to reduce the prevalence of stunting for Indonesian children.
\end{abstract}

Keywords: stunting, children under five years old, coverage of maternal and child health services

\section{INTRODUCTION}

Stunting is a condition of growth failure in children under five due to chronic malnutrition (National Team for the Acceleration of Poverty Reduction, 2017). If a toddler's height is lower than the standard by the World Health Organization Multicentre Growth Reference Study (WHO-MGRS), then the toddler is considered stunted. If the $\mathrm{z}$-score value is less than -2 from the standard deviation (SD), then a child is considered stunted, while a z-score of less than -3 SD indicates a child is severely stunted (Indonesian Ministry of Health, 2018a). Causes of stunting include malnutrition experienced by pregnant women and children under five and limited health services i.e., antenatal care or maternal health services during pregnancy (Sandjojo, 2017). Toddlers who experience stunting will have a suboptimal level of intelligence and will be more susceptible to disease and increased risk of decreased productivity.

Globally, the rate of stunting in the world was $22.2 \%$ in 2017 (150.8 million children under five years old), with $55 \%$ of children under five affected in Asia (WHO, 2017). Reports on the results of Basic Health Research in 2013 showed the prevalence of stunting nationally reached $>$ $30 \%$, although the WHO limit was $<20 \%$. In 2010 , the national prevalence of stunting 
amounted to $35.6 \%$, meaning there was an increase of $1.6 \%$. Of $37.2 \%$ stunting prevalence rate, there were some severely stunted children $(18.0 \%)$ and stunted children (19.2\%) (Indonesian Ministry of Health, 2013). The 2018 Basic Health Research mentioned the prevalence decreased to $36.8 \%$, but this figure was still above $30 \%$ and had not reached the target (Indonesian Ministry of Health, 2018b). The World Bank research results illustrated losses due to stunting reached $3-11 \%$ of gross domestic revenue (GDP). With a 2015 GDP of Rp 11,000 trillion, economic losses due to stunting in Indonesia were estimated to reach between Rp 300 trillion and $\mathrm{Rp} \mathrm{1,210} \mathrm{trillion} \mathrm{per} \mathrm{year} \mathrm{(Sandjojo,}$ 2017).

Various attempts have been made to overcome the problem of stunting; for example, policies have been formulated on priority health development programs. Four priority programs were focused in the 20152019 periods, particularly on reducing maternal and infant mortality, reducing the prevalence of stunting, controlling infectious diseases, and controlling noncommunicable diseases. Efforts to improve the nutritional status of the community and to reduce the prevalence of stunted children are among the national development priorities listed in the main targets of the 2015-2019 Medium-Term Development Plan. The target for stunting prevalence in children under two years (stunted and severely stunted) has been placed at $28 \%$ (Indonesian Ministry of Health, 2018a). In addition to policies on priority health development programs, the Indonesian Ministry of Health has put in a place a specific nutrition intervention program through public health centers and integrated health centers for the first 1,000 days of a child's life. They have also implemented the Supplementary Feeding Program for undernourished children and pregnant women with chronic energy deficiency (CED). Additionally, through the National Team for the Acceleration of Poverty Reduction, a program for 160 priority districts/cities has been launched for the intervention of dwarfism or stunting in children (National Team for the Acceleration of Poverty Reduction, 2017).

Research by Kusumawati et al. (2015) has shown that the percentage of stunting cases was higher in babies born with a history of low birth weight (LBW) and a long family history of birth length/height below $48 \mathrm{~cm}$, babies who struggle with breastfeeding, and babies lacking access to health services and immunization. Further analysis found that toddlers with a history of poor health and immunization services had 3.17 times risk of stunting compared to toddlers with a history of good health and immunization services. Research by Rahayu et al. (2015) showed that children with LBW were 5.9 times more likely to experience stunting than children without LBW. Likewise, a study by Candra and Puruhita (2011) suggested that a history of LBW was one of the risk factors that influenced the incidence of stunting in children 1-2 years old in Semarang City.

While there have been numerous stunting studies across certain regions in Indonesia, there are no studies on the national stunting prevalence that have used individual aggregate data comparing the results between the 2013 and 2018 Basic Health Research. Based on the above problems and the high prevalence of stunting in Indonesia, the research aimed to describe the achievement of coverage of maternal and child health services in Indonesia by comparing the 2013 and 2018 Basic Health Research. The next objective was to explain a correlation between coverage of maternal and child health services with the prevalence of stunting in Indonesia in order to develop a more appropriate strategy to reduce the incidence of stunting.

\section{METHODS}

The study used secondary data from the 2013 and 2018 Basic Health Research 
using a cross-sectional design. The samples were chosen from 33 provinces for the 2013 Basic Health Research and 34 provinces for the 2018 Basic Health Research. Stunting prevalence was aggregate data from individuals using a $\mathrm{z}$-score of the toddler HAZ index based on the anthropometric standards of WHO toddlers in 2005. Variables in maternal health services included the percentage coverage of antenatal care, iron consumption, possession of $\mathrm{MCH}$ books, delivery assistance by health workers, delivery places, and postpartum maternal health services. Child health service variables were measured from the prevalence of LBW, stunted birth length, neonatal examination, immunization, health cards and $\mathrm{MCH}$ book ownership, growth monitoring, consumption of vitamin A capsules, early breastfeeding initiation, colostrum, and prelacteal feeding. Data were analyzed using variance measurements and bivariate analysis through correlations, simple linear regression, and paired T-tests. The data of
Basic Health Research have received ethical clearance approval from the Health Research Ethics Commission of the Indonesian Ministry of Health Research and Development. The 2013 Basic Health Research obtained an ethical clearance certificate number of LB.01.01/51/KE.006/2013, and the 2018 Basic Health Research had an ethical clearance certificate number of LB.02.01/2/KE.024/2018.

\section{RESULTS}

Table 1 shows that variations in the prevalence of stunting in Indonesia were still very wide and subject to $25.4 \%$ in 2013 and $25.1 \%$ in 2018 . The prevalence of stunting in Indonesia still included severe public health problems (the prevalence above $30 \%$ ). There was a significant decrease in the prevalence of severe stunting by $7.4 \%$ between 2013 and 2018, but the prevalence of stunting was not significant $(\mathrm{p}=0.506)$.

Table 1. Prevalence of Stunting in Indonesia

\begin{tabular}{|c|c|c|c|c|c|c|}
\hline \multirow{2}{*}{$\begin{array}{l}\text { Prevalence } \\
\text { of Stunting }\end{array}$} & \multicolumn{2}{|c|}{$2013(\%)$} & \multicolumn{2}{|c|}{$2018(\%)$} & \multirow[t]{2}{*}{$\begin{array}{c}\text { Decrease } \\
(\%)\end{array}$} & \multirow[t]{2}{*}{$\begin{array}{c}\text { P- } \\
\text { value }^{a}\end{array}$} \\
\hline & $\begin{array}{l}\text { Min- } \\
\text { Max }\end{array}$ & $\mathrm{X} \pm \mathrm{SD}$ & $\begin{array}{l}\text { Min- } \\
\text { Max }\end{array}$ & $\mathrm{X} \pm \mathrm{SD}$ & & \\
\hline Severely stunted & $8.2-27.6$ & $\begin{array}{c}18.4 \pm \\
4.5\end{array}$ & $5.6-16.2$ & $11.1 \pm 2.8$ & 7.4 & $0.0001^{\mathrm{a}}$ \\
\hline Stunted & $\begin{array}{l}15.0- \\
25.7\end{array}$ & $\begin{array}{c}19.8 \pm \\
3.3\end{array}$ & $11.5-26.7$ & $19.1 \pm 3.1$ & 0.6 & $0.506^{\mathrm{a}}$ \\
\hline $\begin{array}{l}\text { Percentage of } \\
\text { stunting }\end{array}$ & $\begin{array}{l}26.3- \\
51.7\end{array}$ & $\begin{array}{c}38.2 \pm \\
6.1\end{array}$ & $17.6-42.7$ & $30.3 \pm 5.3$ & 7.8 & $0.0001^{\mathrm{a}}$ \\
\hline
\end{tabular}

aaired T-test. Source: Basic Health Research 2013 and 2018

Table 2 shows the description of maternal health care coverage in Indonesia with wide variations in maternal health care coverage between provinces. The coverage of maternal health services that was still very low was the percentage of $\mathrm{MCH}$ book ownership (37.8\% in 2013 and $47.6 \%$ in 2018) and coverage of health services provided to mothers during the period of 6 hours to 42 days after giving birth $(26.5 \%$ in 2013 and $34.4 \%$ in 2018) 
Table 2. Relationship of Coverage of Maternal Health Services with Prevalence of Stunting Toddlers in Indonesia

\begin{tabular}{|c|c|c|c|c|c|}
\hline $\begin{array}{c}\text { Indicator Coverage } \\
\text { of Maternal Health } \\
\text { Services }\end{array}$ & $\begin{array}{c}\text { Min-Max } \\
(\%)\end{array}$ & $\mathrm{X} \pm \mathrm{SD}$ & $\mathbf{r}$ & $\begin{array}{c}\text { p- } \\
\text { value }^{a}\end{array}$ & $\begin{array}{c}\text { p- } \\
\text { value }^{b}\end{array}$ \\
\hline \multicolumn{6}{|c|}{ Percentage of pregnancy check antenatal care (K4) } \\
\hline Basic Health Research 2013 & $41.4-85.5$ & $63.9 \pm 12.2$ & -0.607 & 0.0001 & \multirow[t]{2}{*}{0.0001} \\
\hline Basic Health Research 2018 & $43.8-90.2$ & $67.3 \pm 11.7$ & -0.44 & 0.009 & \\
\hline \multicolumn{6}{|c|}{ Percentage of iron consumption $\geq 90$ items } \\
\hline Basic Health Research 2013 & $43.2-87.1$ & $63.1 \pm 9.8$ & -0.526 & 0.002 & \multirow[t]{2}{*}{0.0001} \\
\hline Basic Health Research 2018 & $13.9-68.5$ & $32.5 \pm 14.8$ & -0.333 & 0.051 & \\
\hline \multicolumn{6}{|c|}{ Percentage of ownership of MCH books } \\
\hline Basic Health Research 2013 & $14.8-63,5$ & $37.8 \pm 13.6$ & -0.201 & 0.262 & \multirow[t]{2}{*}{0.0001} \\
\hline Basic Health Research 2018 & $22.3-76.4$ & $47.6 \pm 13.6$ & -0.264 & 0.131 & \\
\hline \multicolumn{6}{|c|}{ Percentage of birth health workers } \\
\hline Basic Health Research 2013 & $58.9-99.9$ & $82.7 \pm 12.0$ & -0.572 & 0.001 & \multirow[t]{2}{*}{0.0001} \\
\hline Basic Health Research 2018 & $57.9-99.7$ & $90.6 \pm 9.6$ & -0.3368 & 0.032 & \\
\hline \multicolumn{6}{|c|}{ Percentage of delivery at health facilities } \\
\hline Basic Health Research 2013 & $25.2-99.0$ & $60.9 \pm 21.3$ & -0.625 & 0.0001 & \multirow[t]{2}{*}{0.0001} \\
\hline Basic Health Research 2018 & $30.1-98.5$ & $71.8 \pm 1$ & -0.452 & 0.007 & \\
\hline \multicolumn{6}{|c|}{ Percentage of maternal health services } \\
\hline Basic Health Research 2013 & $8.8-55.5$ & $26.5 \pm 11.9$ & -0.477 & 0.005 & \multirow[t]{2}{*}{0.0001} \\
\hline Basic Health Research 2018 & $16.8-62.4$ & $34.4 \pm 11.4$ & -0.427 & $0.012 \mathrm{o}$ & \\
\hline \multicolumn{2}{|c|}{ Pearson Correlation $\quad$ 'Paired t-test } & \multicolumn{4}{|c|}{ rCorrelation Coefficient } \\
\hline \multicolumn{2}{|c|}{$\begin{array}{l}\text { The analysis results of the } 2013 \\
\text { Basic Health Research showed that } \\
\text { maternal health service indicators related to } \\
\text { the prevalence of stunting were the } \\
\text { complete coverage of pregnancy checks } \\
\text { during antenatal care (K4), iron } \\
\text { consumption, health worker birth } \\
\text { attendants, delivery in health facilities, } \\
\text { puerperal maternal health services; the } \\
\text { indicators were also observed in the } 2018 \\
\text { Basic Health Research, except iron } \\
\text { consumption coverage (Table 2). The } \\
\text { higher the coverage of maternal health } \\
\text { services, the lower the stunting prevalence. } \\
\text { The bivariate analysis results with the } \\
\text { paired t-test showed a significant increase }\end{array}$} & \multicolumn{4}{|c|}{$\begin{array}{l}\text { ( } \mathrm{p}<0.0001) \text {, except coverage of Fe tablet } \\
\text { consumption from } 63.1 \% \text { in } 2013 \text { to } 32.5 \% \\
\text { in } 2018 \text {. } \\
\text { Table } 3 \text { shows the coverage of } \\
\text { neonatal visits increased, but the } \\
\text { achievement of complete neonatal } \\
\text { examination coverage was still very low } \\
(43.5 \% \text { ). The coverage of complete } \\
\text { immunization for children under five in } \\
\text { Indonesia decreased slightly from } 59.2 \% \text { in } \\
2013 \text { to } 57.9 \% \text { in } 2018 \text {. The most common } \\
\text { reasons that mothers of children under five } \\
\text { had not weighed children aged } 6-59 \text { months } \\
\text { for the past six months was because the } \\
\text { child was already older ( } \geq 1 \text { year) and the } \\
\text { mothers were busy. }\end{array}$} \\
\hline
\end{tabular}


Table 3. Characteristics of Children Health Services in Indonesia

\begin{tabular}{|c|c|c|}
\hline Characteristics of Children Health Services & $\begin{array}{l}\text { Basic Health } \\
\text { Research } 2013\end{array}$ & $\begin{array}{l}\text { Basic Health } \\
\text { Research } 2018\end{array}$ \\
\hline \multicolumn{3}{|l|}{ Neonatal visits } \\
\hline KN1 (6-48 hours) & 71.3 & 84.1 \\
\hline KN2 (days) & 61.3 & 71.1 \\
\hline KN3 (8-28 days) & 47.5 & 50.5 \\
\hline $\mathrm{KN}$ complete $(\mathrm{K} 4)$ & 39.3 & 43.5 \\
\hline \multicolumn{3}{|l|}{ Types of immunization } \\
\hline $\mathrm{HB}-0$ & 79.1 & 83.1 \\
\hline $\mathrm{BCG}$ & 87.6 & 86.9 \\
\hline DPT-HB3 & 75.6 & 61.3 \\
\hline Polio 4 & 77.0 & 67.6 \\
\hline Measles & 82.1 & 77.3 \\
\hline \multicolumn{3}{|l|}{ Completeness of immunization } \\
\hline Complete immunization & 59.2 & 57.9 \\
\hline Incomplete immunization & 32.1 & 32.9 \\
\hline No immunization & 8.7 & 9.2 \\
\hline \multicolumn{3}{|c|}{ Reasons for mother not to weigh children 6-59 months old } \\
\hline Child is old ( $\geq 1$ year) & 27.2 & 14.1 \\
\hline Children have finished immunization & 10.0 & 10.8 \\
\hline Children do not want to measure their & & 8.1 \\
\hline weight & 7.9 & \\
\hline Bored if only weighed & 1.6 & - \\
\hline Forgot/do not know the schedule & 7.6 & 12.8 \\
\hline No place for measuring baby weight & 3.1 & 2.8 \\
\hline Remote place & 9.9 & 6.8 \\
\hline Busy/hassle & 24.2 & 28.3 \\
\hline Lazy & 8.6 & 15.1 \\
\hline Unavailable & - & 1.3 \\
\hline
\end{tabular}

Source: Basic Health Research 2013 and 2018

Table 4. Relationship of Coverage of Child Health Services with Prevalence of Stunting in Indonesia

\begin{tabular}{|c|c|c|c|c|c|}
\hline Coverage Indicators & $\begin{array}{c}\operatorname{Min}-M a x \\
(\%)\end{array}$ & $X \pm \operatorname{SD}(\%)$ & $\begin{array}{l}\text { Correlation } \\
\text { Coefficient }\end{array}$ & $\begin{array}{c}\mathbf{p} \\
\text { values }^{\mathrm{a}}\end{array}$ & $\underset{\text { values }}{\mathbf{p}}$ \\
\hline \multicolumn{6}{|c|}{ Prevalence of low birth weight (LBW) } \\
\hline Basic Health Research 2013 & 7.2-16.8 & $10.7 \pm 2.4$ & 0.370 & 0.034 & 0.000 \\
\hline Basic Health Research 2018 & $2.6-8.9$ & $6.2 \pm 1.3$ & 0.119 & 0.502 & 1 \\
\hline \multicolumn{6}{|l|}{ Prevalence of stunted birth length } \\
\hline Basic Health Research 2013 & $9.6-28.7$ & $20.1 \pm 4.8$ & 0.019 & 0.915 & \multirow{2}{*}{0.029} \\
\hline Basic Health Research 2018 & $11.7-81.4$ & $25.1 \pm 11.5$ & -0.332 & 0.062 & \\
\hline \multicolumn{6}{|c|}{ Percentage of neonatal examinations (K4) } \\
\hline Basic Health Research 2013 & $9.2-58.3$ & $32.3 \pm 12,6$ & -0.499 & 0.003 & \multirow{2}{*}{$\begin{array}{c}0,000 \\
1\end{array}$} \\
\hline Basic Health Research 2018 & $14.7-71.3$ & $37.0 \pm 14.3$ & -0.469 & 0.005 & \\
\hline \multicolumn{6}{|c|}{ Percentage of complete immunization } \\
\hline Basic Health Research 2013 & $29.2-83.1$ & $55.5 \pm 15.1$ & -0.449 & 0.004 & \multirow{2}{*}{0.911} \\
\hline Basic Health Research 2018 & $19.5-92.1$ & $56.2 \pm 16.8$ & -0.484 & 0.004 & \\
\hline
\end{tabular}




\begin{tabular}{|c|c|c|c|c|c|}
\hline Coverage Indicators & $\begin{array}{c}\text { Min-Max } \\
(\%)\end{array}$ & $\mathrm{X} \pm \mathrm{SD}(\%)$ & $\begin{array}{l}\text { Correlation } \\
\text { Coefficient }\end{array}$ & $\begin{array}{c}\mathbf{p} \\
\text { values }^{\mathbf{a}}\end{array}$ & $\underset{\mathbf{b}}{\mathbf{p}}$ \\
\hline \multicolumn{6}{|c|}{ Percentage of not having a health card } \\
\hline Basic Health Research 2013 & $39.7-48.1$ & $58.9 \pm 10.1$ & -0.405 & 0.019 & 0.000 \\
\hline Basic Health Research 2018 & $10.8-48.1$ & $26.7 \pm 9.28$ & -0.002 & 0.991 & 1 \\
\hline \multicolumn{6}{|c|}{ Percentage of absence of under-five growth monitoring } \\
\hline Basic Health Research 2013 & $7.2-65.4$ & $40.3 \pm 13.8$ & 0.406 & 0.019 & 0.000 \\
\hline Basic Health Research 2018 & 4.4-47.6 & $23.8 \pm 10.1$ & 0.277 & 0.113 & 1 \\
\hline \multicolumn{6}{|l|}{ Percentage of vitamin A } \\
\hline Basic Health Research 2013 & $52.3-89.2$ & $71.8 \pm 8.8$ & -0.301 & 0.089 & 0.000 \\
\hline Basic Health Research 2018 & $32.4-65.1$ & $50.5 \pm 7.6$ & -0.274 & 0.116 & 1 \\
\hline \multicolumn{6}{|c|}{ Percentage of early breastfeeding initiation $<1$ hour } \\
\hline Basic Health Research 2013 & $21.7-52.9$ & $33.7 \pm 7.8$ & -0.053 & 0.770 & 0.000 \\
\hline Basic Health Research 2018 & $34.3-74.1$ & $54.6 \pm 9.8$ & -0.194 & 0.272 & 1 \\
\hline \multicolumn{6}{|l|}{ Percentage of giving colostrums } \\
\hline Basic Health Research 2013 & $84.8-98.3$ & $93.6 \pm 3.4$ & -0.149 & 0.409 & 0.000 \\
\hline Basic Health Research 2018 & 49.4-97.7 & $8.9 \pm 82.6$ & -0.17 & 0.336 & 1 \\
\hline \multicolumn{6}{|l|}{ percentage of prelacteal feeding } \\
\hline Basic Health Research 2013 & $22.2-62.7$ & $9.8 \pm 43.1$ & -0.204 & 0.255 & 0.000 \\
\hline Basic Health Research 2018 & $13.2-59.3$ & $32.7 \pm 9.44$ & -0.109 & 0.541 & 1 \\
\hline
\end{tabular}

Table 4 shows a description of children's health services in Indonesia; there were quite wide variations between provinces. There were some problematic cases in terms of the coverage of neonatal examination between 9.2\%-58.3\%; complete immunization coverage between 29.2\%-55.5\%; coverage of health card ownership with a range of $13 \%-45 \%$; coverage of children under five never weighed nor monitored ranging from $7.2 \%$ $65.4 \%$; coverage of early breastfeeding initiation between $21.7 \%-52.9 \%$; and the percentage of pre-actual feeding between $22.2 \%-62.7 \%$.

Table 4 also shows that there were significant differences in the coverage of child health service indicators, except that immunization coverage with no significant change between 2013 and $2018(\mathrm{p}=0.911)$. Child health services could be improved by reducing the prevalence of LBW infants, covering full neonatal examinations, monitoring growth and development, administering IMD, and prelacteal feeding. The prevalence of babies born with LBW dropped significantly from $10.7 \%$ in 2013 to $6.2 \%$ in 2018 . The coverage of complete neonatal examinations increased significantly from $32.3 \%$ in 2013 to $37 \%$ in 2018. There was a decrease in the percentage of children under five who had never been weighed from $40.3 \%$ in 2013 to $23.8 \%$ in 2018 . There was a significant increase in the coverage of early breastfeeding initiation within less than an hour from $33.7 \%$ in 2013 to $54.6 \%$ in 2018 . There was a decrease in the percentage of pre-actual feeding from $43.1 \%$ in 2013 to $32.7 \%$ in 2018.

The decreased coverage of child health services was found in some variables i.e., babies born with stunted birth lengths, health card ownership, provision of vitamin $\mathrm{A}$, and provision of colostrum. The prevalence of babies born with a stunted birth length $(<48 \mathrm{~cm})$ increased from $20.1 \%$ in 2013 to $25.1 \%$ in 2018 , and that of children under five without a health card increased from $23.2 \%$ in 2013 to $26.7 \%$ in 2018. The coverage of vitamin A administration decreased from $71.8 \%$ in 2013 to $50.5 \%$ in 2018 , so was the coverage 
of colostrum administration from $93.6 \%$ in 2013 to $82.6 \%$ in 2018.

The correlation analysis and linear regression results of 2013 Basic Health Reseearch showed no significant relationship between LBW and stunting. There was a significant and negative relationship between neonatal examination coverage, complete immunization coverage, ownership of health cards and $\mathrm{MCH}$ books, and children under five who were never weighed or monitored with the prevalence of stunting. These results indicated that the lower the percentage of child health service coverage, the higher the prevalence of stunting in children under five in Indonesia. There was no correlation between the prevalence of stunted birth length with vitamin A administration, early breastfeeding initiation, colostrum administration, or prelacteal feeding.

\section{DISCUSSION}

The results showed that the prevalence of stunting in toddlers in the 2018 Basic Health Research decreased by $7.8 \%$ compared to the 2013 Basic Health Research. A significant decrease occurred in the prevalence of very short toddlers, while the prevalence of short toddlers was not significantly different. Despite the decline, the prevalence of stunting was still a serious problem because it went from $26.3 \%$ to $51.7 \%$ (WHO, 2010). When compared between provinces, the variations were also quite wide. The lowest prevalence was in Riau Islands, Special Region of Yogyakarta, Special Capital Region of Jakarta, and East Kalimantan $(<30 \%)$, while the highest was in East Nusa Tenggara $(>50 \%)$. The prevalence of stunted toddlers in Indonesia was even higher than in India among children aged 2 years $(25.7 \%), 3$ years $(26.4 \%), 4$ years $(24.5 \%), 5$ years $(27.6 \%)$, and 6 years (30.5\%) (Bose and Mandal, 2010), and it was also higher than the average prevalence of stunting in the world at $26.7 \%$ (WHO, 2017). The decrease in stunting prevalence is related to various efforts of maternal and child health services that have been carried out by the government. This can be seen in the increase in coverage of maternal and child health services reported in the 2013 and 2018 Basic Health Research.

The maternal health service coverage based on the 2018 Basic Health Research showed an increase in the percentage of antenatal care (ANC), complete pregnancy check, ownership of $\mathrm{MCH}$ handbook, delivery in health facilities, and postnatal maternal health services. The 2018 Basic Health Research showed the percentage of health workers helping deliveries decreased compared to the 2013 Basic Health Research. Efforts should be improved in achieving more maternal health services, especially the coverage of iron consumption ( $\geq 90$ tablets) and the number of health workers helping deliveries.

The coverage of pregnancy check and antenatal care was negatively associated with stunting prevalence. The higher the coverage of complete ANC, the lower the stunting prevalence. This is in line with the research in Mataram where mothers who did not comply with antenatal care standards had 2.3 times risk of having a stunted toddler than mothers who received standard antenatal care. The standard antenatal care visits amount to four visits during pregnancy (Najahah et al., 2013).

The coverage of iron consumption was significantly, negatively related to stunting prevalence. The higher the percentage of iron consumption coverage, the lower the prevalence of stunting. The results found that mothers who consumed less than $90 \mathrm{Fe}$ tablets during pregnancy had the risk of having a toddler who experienced linear growth disorders. Failure to grow in toddlers was closely related to the lack of nutrient intake. Research in Nepal showed that pregnant women who consumed iron and folic acid could prevent stunting in children younger than 2 years $(\mathrm{RR}=0.86 ; 95 \% \mathrm{CI}=$ 0.77-0.97). Pregnant women who consumed more than 90 iron and folic acid tablets before 6 months prior to giving birth could reduce the risk of stunting by $23 \%(\mathrm{RR}=0.77 ; 95 \%$ $\mathrm{CI}=0.64-0.92)$. $\mathrm{Fe}$ and folate tablets 
consumption significantly reduced the risk of stunting in Nepali children aged $<2$ years (Nisar, Dibley, and Aguayo, 2016). Anemia during pregnancy is a problem that often occurs in developing countries, including Indonesia. The results found that both mothers consuming less than 90 Fe tablets and more had $42 \%$ and $35.5 \%$ of children under five born with linear growth disorders, respectively.

Fe tablet consumption was associated with impaired linear growth of infants in the womb due to anemia in pregnant women. Simbolon's (2013) research found there were differences in the average birth weight of infants, in which infants with 440.7 grams were more in non-anemic pregnancies. Anemic pregnant women had 6.4 times the risk of giving birth to a LBW baby. Anemia in pregnant women can increase the risk of morbidity and mortality of mothers and babies, and the possibility of giving birth to LBW and premature babies is also greater.

Anemic pregnant women were at risk of giving birth to shorter babies $(51.76 \mathrm{~cm})$ compared to mothers who were not anemic $(55.54 \mathrm{~cm})$. They were also more prone to giving birth to babies with lower body weight (3,048 grams) compared to mothers without anemia (3,615.6 grams) (Lelic et al., 2014). Anemia can be a direct cause of growth disoders due to increased oxygen in placental tissue and an indirect effect of malnourishment. pregnant women taking dangerous substances are twice more likely to give birth to LBW and premature babies (Yildiz et al., 2014).

The results proved that delivery helped by health workers and the coverage of deliveries in health facilities were significantly related to the prevalence of stunting. The lower the delivery helped by health workers and the coverage of delivery in health facilities, the higher the prevalence of stunting. The prevalence of LBW was significantly, positively related to the prevalence of stunting. The higher the prevalence of LBW, the higher the prevalence of stunting. Some research also proved that the lower the birth weight, the higher the risk of toddlers experiencing growth disorders. Research by Espo et al. (2007) found that the strongest predictor of stunting in 12 months of age was low birth weight. Most babies with LBW experience growth disoders in childhood. In Asian countries such as Bangladesh, China, India, Pakistan, the Philippines, and Sri Lanka, LBW could be a predictor factor of nutritional status among pre-school children. A conclusion from 12 studies stated that babies with intra-uterine growth retardation (IUGR) experienced growth failure in the first two years. At the age of 17 to 19 years, men and women born with IUGR-LBW were $5 \mathrm{~cm}$ shorter and $5 \mathrm{~kg}$ skinner compared to children born normally (Allen, 2014). The results of this study are also in line with research by Oktarina and Sudiarti (2014) who found a relationship between birth weight and the incidence of stunting in infants. Toddlers with LBW had 1.31 times risk of stunting compared to normal ones. Birth weight is a strong predictor of future body size. Babies with LBW experience growth retardation in the uterus, both acute and chronic (Akram and Arif, 2005).

The results found that the coverages of postnatal maternal health service and neonatal examination were significantly, negatively correlated with stunting; the higher the coverage of postnatal maternal health service and the lower the coverage of neonatal examination, the lower the prevalence of stunting. Good postpartum care is very important because most maternal and newborn deaths occur in the first two days; further, postnatal care is necessary to handle complications after delivery. The Riau Islands, East Nusa Tenggara, and Papua showed the worst performance in this regard. The coverage of timely post-delivery services only at $18 \%$ in the Riau Islands. Around 26\% of all postpartum mothers received postpartum care (UNICEF Indonesia, 2012).

The 2013 and 2018 Basic Health Research indicated that the coverage of neonatal service increased, while the coverage of BCG, DPT-HB3, and measles 
immunization and complete immunization decreased. The reasons for mothers not taking their children's weight measured in integrated health centers varied. In 2013, the most common reason was that the children were older than 1 year old. The 2018 Basic Health Research showed the most common was they were busy. These results indicated the need for frequent visits to integrated health centers for infant growth and development monitoring and complete immunization.

As many as $41.1 \%$ of the children who were not fully immunized had experienced a linear growth disorder, so did $32.5 \%$ of the children with complete immunization. The research results of Picauly and Toys (2013) in Kupang and East Sumba, East Nusa Tenggara also found that incomplete basic immunization was a risk factor for stunting. Children who had no history of immunization had a greater chance of stunting than children who had a history of immunization. If the child were not immunized, they will have an increased risk of stunting. Children who did not get complete immunization had seven times risk of experiencing linear growth disorders $(95 \%$ $\mathrm{OR}=1,256-42,014)$. These results are in line with the study of Kusumawardani et al. (2019), which stated that the completeness of immunization had a significant effect on stunting. Immunization is done by injecting vaccines into the body to become resistant to diseases that are endemic or dangerous.

Picauly and Toy (2013) also found that children who had a history of infectious disease had a greater chance of stunting than children who did not. If children had a history of disease and/or infection, they were 2.332 times more likely to be stunted. The results of this study are in line with research by Yustisia (2019), which stated that infectious diseases had a significant effect on the prevalence of stunting in children aged 24-59 months. Severe infections can worsen nutritional conditions due to poor food input and loss of the essential nutrients through vomiting and diarrhea. Infectious diseases such as respiratory infections can also reduce appetite.

Ownership of health cards and $\mathrm{MCH}$ books and the coverage of growth monitoring were significantly related to the incidence of stunting. The lower the coverage of having health cards and MCH books, the higher the prevalence of stunting. The results are in line with the research in Sidoarum village, Sleman, Yogyakarta where the frequency of growth monitoring was the most dominant factor of stunting in children aged $3-5$ years $(\mathrm{OR}=3.1$; 95\% $\mathrm{CI}=1,268-7,623)$. Children who were less actively going to an integrated health center were 3.1 times more at risk of being stunted than children who regularly visited it (Destiadi et al., 2013). Research by Kenney et al. (2013) showed that frequent visits of mothers and children under five to health service facilities had a significant relationship with the child's nutritional status. Integrated health centers are places to monitor the nutritional status and growth of children regularly, including their weight and height. Visiting integrated health centers is an indicator of community access to basic health services such as growth and development monitoring. Mothers who actively visit integrated health centers will get more information about maternal and child health; therefore, they are accounted to care for children well. Besides, integrated health centers is to improve nutritional status, reduce malnutrition, and reduce infant mortality (Indonesian Ministry of Health, 2012).

\section{CONCLUSION}

The prevalence of stunting in Indonesia is a serious public health problem. As shown in the 2013 and 2018 Basic Health Research, the prevalence of stunting decreased significantly, especially the prevalence of severe stunting. The decline was associated with an increase in the coverage of maternal and child health services from 2013 to 2018. Optimal interventions may increase the coverage of 
maternal and child health services in reducing the prevalence of stunting in Indonesia.

\section{REFERENCES}

Akram, D. S., and Arif, F. (2005) 'Ponderal index of low birth weight babies - A hospital-based study', Journal of the Pakistan Medical Association, 55(6), pp. 229-231.

Allen LH, and Gillespie. (2014) What Works? A Review of the Efficacity and Effectiveness of Nutrition Interventions. Asian Development Bank with the UN ACC SubCommittee on Nutrition. Geneva in collaboration with the Asian Development Bank, Manila.

Bose, K. and Mandal, G. C. (2010) 'Proposed new anthropometric indices of childhood undernutrition', Malaysian Journal of Nutrition, 16(1), pp. 131-136.

Candra, A. and Puruhita, N. (2011) 'Risk Factors of Stunting Among 1-2 Years Old Children in Semarang City', Media Medika Indonesiana, 45(3), pp. 206-212.

Destiadi, A., Susila, T. and Sumarmi, S. (2013) 'Frekuensi Kunjungan Integrated Health Center dan Riwayat Kenaikan Berat badan sebagai Faktor Risiko Kejadian Stunting pada Anak Usia 3-5 Tahun', Media Gizi Indonesia, Vol.10 No., p. hlm.71-75.

Espo, M. et al. (2007) 'Determinants of linear growth and predictors of severe stunting during infancy in rural Malawi', Acta Paediatrica, 91(12), pp. 1364-1370. DOI:

$10.1111 / \mathrm{j} .1651-$

2227.2002.tb02835.x.

Kenney, G. M., Anderson, N. and Lynch, V. (2013) 'Medicaid / CHIP Participation Rates Among Children : An Update Timely Analysis of Immediate Health Policy Issues', (September).

Kusumawardani DA, Irawan R, and
Purnomo W. (2019) 'Child Health Care Practices and Stunting in Children Aged 12-36 Months in Jember Regency of Indonesia', 10(8), pp. 34-39.

Kusumawati, E., Rahardjo, S. and Sari, H. P. (2015) 'Model Pengendalian Faktor Risiko Stunting pada Anak Bawah Tiga Tahun', Kesmas: National Public Health Journal, 9(3), p. 249. doi: 10.21109/kesmas.v9i3.572.

Lelic, M. et al. (2014) 'Influence of maternal anemia during pregnancy on placenta and newborns.', Medicinski arhiv, 68(3), pp. 184-187. DOI: 10.5455/medarh.2014.68.184-187.

Indonesian Ministry of Health (2012) Pedoman Umum Pengelolaan Integrated Health Center, Kementerian Kesehatan RI. Jakarta.

Indonesian Ministry of Health (2013) LAPORAN RISET KESEHATAN DASAR 2013.

Indonesian Ministry of Health (2018a) 'Situasi Balita PEndek (Stunting) di Indonesia', in Buletin Jendela Data dan Informasi Kesehatan. Pusat Data Informasi Ministry of Health.

Indonesian Ministry of Health (2018b) Laporan Nasional Riset Kesehatan Dasar 2018, Kementerian Kesehatan $R I$.

Najahah, I., Adhi, K. T. and Pinatih, G. N. I. (2013) 'Faktor risiko balita stunting usia 12-36 bulan di Puskesmas Dasan Agung, Mataram, Provinsi Nusa Tenggara Barat', Public Health and Preventive Medicine Archive, 1(2), $\mathrm{p}$. 103. doi: 10.15562/phpma.v1i2.171.

Nisar, Y. Bin, Dibley, M. J. and Aguayo, V. M. (2016) 'Iron-folic acid supplementation during pregnancy reduces the risk of stunting in children less than 2 years of age: A retrospective cohort study from Nepal', Nutrients, 8(2):1-16. DOI: 10.3390/nu8020067.

Oktarina, Z. and Sudiarti, T. (2014) 'Faktor Risiko Stunting Pada Balita (24-59 Bulan) Di Sumatera', Jurnal Gizi dan 
Pangan, 8(3), p. 177. doi: 10.25182/jgp.2013.8.3.177-180.

Picauly, I. and Toy, S. M. (2013) 'Analisis Determinan Dan Pengaruh Stunting Terhadap Prestasi Belajar Anak Sekolah Di Kupang Dan Sumba Timur, Ntt', Jurnal Gizi dan Pangan, $8(1), \quad$ p. $55 . \quad$ doi: 10.25182/jgp.2013.8.1.55-62.

Rahayu, A. et al. (2015) 'Riwayat Berat Badan Lahir dengan Kejadian Stunting pada Anak Usia Bawah Dua Tahun', Jurnal Kesehatan Masyarakat Nasional, 10(2), pp. 6773. doi: 10.21109/kesmas.v10i2.882. Sandjojo, E. (2017) 'Buku saku desa dalam penanganan stunting', Buku Saku Desa Dalam Penanganan Stunting, p. 42.

Simbolon, D. (2013) 'Model Prediksi Indeks Massa Tubuh Remaja Berdasarkan Riwayat Lahir dan Status Gizi Anak', Kesmas: National Public Health Journal, 8(1), p. 19. DOI 10.21109/kesmas.v8i1.337.
National Team for the Acceleration of Poverty Reduction (2017) 100 Kabupaten/Kota Prioritas untuk Intervensi Anak Kerdil (Stunting). Sekretariat Wakil Presiden Republik Indonesia.

UNICEF Indonesia (2012) 'Kesehatan Ibu \& Anak', in UNICEF Indonesia.

WHO (2017) Stunted growth and development, Context, Causes, and Consequences. Geneva

Yildiz, Y. et al. (2014) 'The relationship between third-trimester maternal hemoglobin and birth weight/length; Results from the tertiary center in Turkey', Journal of Maternal-Fetal and Neonatal Medicine, 27(7), pp. 729-732. DOI: 10.3109/14767058.2013.837445.

Yustisia, Y., Anmaru, R. and Laksono, B. (2019) 'The Influencing Factor Analysis of Stunting Incidence in Children Aged 24-59 Months At Kedung Jati Village', 4(2), pp. 116121. 